\title{
PENERAPAN MEDIA PEMBELAJARAN INETRAKTIF BERBASIS MULTIMEDIA PADA PEMBELAJARAN MATERI MOTOR BAKAR SMK
}

\author{
Mikhael Sihombing ${ }^{1}$, Efendi Napitupulu ${ }^{2}$ Farihah $^{3}$ \\ SMK Nila Harapan Deli Serdang ${ }^{1}$, Universitas Negeri Medan ${ }^{2,3}$ \\ mikhaelsimhombing@gmail.com
}

\begin{abstract}
Abstrack : Penelitian ini bertujuan untuk menghasilkan pembelajaran interaktif layak media menggunakan dan efektif dalam meningkatkan hasil pembelajaran mesin konversi energi materi motor bakar. Metode yang digunakan dalam penelitian ini adalah model pembangunan Borg dan empedu, diadaptasi menjadi model sederhana. Penelitian dilakukan di SMK Nila Harapan Deli Serdang. Sampel terdiri dari abjad percobaan kelas (36 siswa) dan kontrol kelas (34 siswa). Hasil pengujian hipotesis membuktikan bahwa ada perbedaan yang signifikan antara hasil pembelajaran siswa yang menggunakan media interaktif pembelajaran dengan mahasiswa belajar hasil hasil menengah yang menggunakan media interaktif pembelajaran dengan hasil belajar siswa menggunakan media cetak. Itu ditunjukkan oleh hasil analisis untuk menghitung $T>T$ meja $(9.77>2.00)$.
\end{abstract}

Kata Kunci : Media Pembelajaran Interaktif; Multimedia; Motor Bakar

\begin{abstract}
This research aims to produce a viable interactive learning media use and are effective in enhancing energy conversion Machine learning results. The methods used in this research are the development model of the Borg and Gall, adapted into a simple model. Research conducted at Nila Harapan Deli Serdang Vocational High School. The samples consist of alphabets experiment class (36 students) and control classes (34 students). Hypothesis testing results prove that there is a significant difference between the learning outcomes of students who use media interactive learning with student learning results intermediate results that use interactive learning media with results Learning students use print media. It was shown by the results of the analysis to calculate $T>T_{\text {table }}(9.77>2.00)$.
\end{abstract}

Key Words: Interactive Learning Media; Multimedia; Energy Conversion Machines.

\section{PENDAHULUAN}

Peningkatan kualitas sumber daya manusia (SDM), dalam amanat UndangUndang Nomor 20 Tahun 2003 tentang Sistem Pendidikan Nasional, Pasal 3 menyatakan bahwa "Pendidikan Nasional berfungsi mengembangkan kemampuan dan membentuk watak serta peradaban bangsa yang bermartabat dalam rangka mencerdaskan kehidupan bangsa, bertujuan untuk berkembangnya potensi peserta didik agar menjadi manusia yang beriman dan bertakwa kepada Tuhan Yang Maha Esa, berakhlak mulia, sehat, berilmu, cakap, kreatif, mandiri, dan menjadi warga negara yang demokratis serta bertanggung jawab".Fenomena diatas juga terlihat pada Pembelajaran Matematika di Sekolah Menengah Pertama yaitu banyak siswa yang mengalami kesulitan dalam belajar, merasa kurang menarik dan sulit untuk memahami bacaan buku teks sehingga berdampak pada rendah nya prestasi belajar.

Teknologi multimedia berkembang sangat cepat dalam dua dekade ini. Salah satu teknologi multimedia mulai populer saat ini adalah teknologi multimedia. Perusahan raksasa
Google, Microsof dan Intel beberapa tahun terakhir telah meluncurkan perangkat AR. Google Glass dan Holo Lens merupakan perangkat augmented yang dikembangakan oleh Google dan Microsoft.(http://googleglass//ok ). Pada pemahaman suatu bacaan, Goodman (dalam Wayan, 2003:4) mengemukakan bahwa pembaca menggunakan sistem simbul (cue system) secara serentak yaitu graphophonic, syntactic, dan semantic. Melalui tiga sistem simbul ini pembaca meramalkan makna teks. Itu berarti dalam upaya pemahaman bacaan akan terjadi interaksi komunikasi antara pembaca dan teks yang dibaca. Tindakan membaca melibatkan unsur pembaca, teks, dan interaksi antara pembaca dan teks.

Pengembangan sebuah media pembelajaran yang melibatkan dua unsur secara bersamaan, yakni verbal dan nonverbal cukup jarang dilakukan. Penelitian ini mencoba untuk mengembangkan sebuah media yang melibatkan unsur verbal yang diwakili oleh teks bacaan dan media nonverbal berupa proyeksi tiga dimensi secara bersamaan dengan 
memanfaatkan teknologi multimedia.

Khairnar (2016:1) melakukan penelitian mengembangkan sebuah multimedia dalam membantu pelanggan dalam menentukan posisi fornitur Rumah. Media Pembelajaran berbasis multimedia ini menggunakan marker yang dapat dipindahkan kemana-mana dan diposisikan sesuai dengan keinginan pelanggan. Tiap marker akan merepresentasikan furnitur perlengkapan rumah yang berbeda-beda.

Pengembangan multimedia juga dilakukan oleh Mauro (2015:1). Mauro menggunakan teknologi AR dalam pembelajaran Mesin Konversi Energi. Mauro memanfaatkan multimedia interaktif untuk menyediakan kegiatan yang siswa dapat lakukan dirumah dan meningkatkan waktu yang dihabiskan bagi siswa untuk belajar dan mempraktekkan di bidang keahlian teknik mesin materi Motor Bakar. Multimedia yang digunakan berbeda-beda untuk menampilkan solusi dari masalah praktis dengan menggunakan berbagai media termasuk menggunakan video.

Selanjutnya Magdalena (2016:184) mengembangkan sebuah aplikasi yang menggunakan media pembelajaran dalam pendidikan. Media Pembelajaran tersebut mengintegrasikan konten pendidikan geosains kedalam dunia nyata yang disebut Field Play. Field Play memiliki dua tujuan utama, yakni meningkatkan akses informasi sains yang berlimpah dalam linkungan sekitar dan mempromosikan pendidikan sains dalam skala yang besar.

Telah banyak penelitian yang dilakukan mengenai penerapan multimedia dalam dunia pendidikan. Peng Chen telah melakukan survey (2016:13) terhadap 55 penelitian yang dipublikasikan antara tahun 2011 dan 2016 mengenai state of the art dalam penelitian media pembelajaran dalam dunia pendidikan. Survei tersebut menjelaskan mengenai kecenderungan dan visi kedepan serta peluang penelitian multimedia dalam dunia pendidikan.

Mayer mengatakan (Sriadhi, 2014: 115) Teori Kognitif multimedia (Cognitive Theory of Multimedia Learning) dari Clark \& Mayer merupakan perpaduan antara Cognitive Load Theory dari Sweller, Dual-Coding Theory dari Pavio dan Working Memory dari Baddeley. Pemrosesan informasi terjadi dalam tiga tahapan penting, yaitu memilih bahan yang sesuai, menyusun bahan terpilih dan menggabukannya dengan pengetahuan yang sudah dimiliki sebelumnya.

Proses pemilihan bahan terjadi ketika individu memberi perhatian kepada bahan yang disampaikan melalui multimedia, dan membawanya masuk ke memori kerja. Selanjutnya dilakukan integrasi bahan yang telah disusun dengan pengetahuan yang sudah dimiliki sebelumnya dari memori jangka panjang ke memori kerja. Aliran pemrosesan informasi dinyatakan dalam model teori kognitif pembelajaran multimedia.

Manusia berfikir, membaca dan memahami beberapa kalimat dalam waktu serentak. Memori kerja akan memproses informasi verbal dan visual dalam saluran yang berbeda. Animasi memasuki sistem kognitif melalui mata dan diproses dalam saluran visual, sedangkan narasi masuk melalui telinga dan diproses dalam saluran auditori. Namun teks pada paparan juga masuk melalui mata dan diproses di saluran visual. Sumber kogntif yang terbatas di saluran visual dibagi dalam pemrosesan informasi, animasi dan teks.

Pemrosesan informasi berlangsung dalam tiga tahapan, yaitu (1) Memilih bahan yang sesuai; (2) Menyusun bahan terpilih dan menggabungnya dengan pengetahuan yang sudah dimiliki; (3) Proses pemilihan bahan terjadi ketika individu memberi perhatian kepada bahan yang disampaikan melalui multimedia, dan membawanya masuk ke memori kerja dalam sistem kognitif. Proses penyusunan bahan yang sudah terpilih dilakukan melalui seleksi dalam memori kerja yang selanjutnya dilakukan integrasi dengan pengetahuan yang sudah dimiliki sebelumnya dari memori jangka panjang ke memori kerja.

Skema pada gambar 3. diatas menetapkan empat prisnsip penelitian dalam sains kognitif Clark \& Mayer (Sriadhi, 2014: 116) yaitu: Dual channel, manusia memproses informasi bentuk visual atau gambar dan auditori atau verbal dalam saluran yang terpisah. Limited capacity, manusia dapat melakukan proses aktif hanya pada sebagian informasi di setiap saluran pada satu waktu tertentu. Active processing, pembelajaran terjadi ketika individu terlibat dalam proses kogntif, seperti memperhatikan materi yang relevan, mengorganisasi materi ke dalam struktur koheren, dan mengintegrasikan dengan pengetahuan yang sudah mereka ketahui. Transfer, pengetahuan baru dan keterampilan harus diambil dari memori jangka panjang selama proses.

Menurut Mayer teori kognitif pembelajaran 
yang disajikan pada Gambar 2 didasarkan pada teori beban kognitif dengan fokus mengurangi beban kognitif siswa. Teori beban kognitif memuat tiga jenis pengolahan kognitif selama belajar. Pertama, beban kognitif intrinsic (intrinsic cognitive load) merupakan beban pikiran dialami siswa selama pembelajaran yang diakibatkan tuntutan konten. Kedua, beban kognitif germane (germane cognitive load) merupakan beban pikiran yang dialami siswa selama pembelajaran yang diakibatkan oleh tuntutan untuk mengintegrasikan informasi baru dengan pengetahuan sebelumnya. Ketiga, beban kognitif extraneous (extraneous cognitive load) merupakan beban pikiran yang dialami siswa selama pembelajaran yang diakibatkan oleh kerja pikiran yang tidak sesuai dengan tujuan pembelajaran. Menurut Sweller (Damayanti, 2010: 133), jika kapasitas kognitif siswa kelebihan beban (overload cognitive) maka pembelajaran akan terganggu. Sehingga untuk mengatasi kesulitan belajar siswa antara lain melalui pembelajaran yang efektif dengan mengelola beban kognitif intrinsik, mengurangi beban kognitif extraneous dan meningkatkan beban kognitif germane. Mayer dan Moreno (Damayanti, 2010:133) menegaskan bahwa untuk mewujudkan pembelajaran yang efektif dapat dibantu dengan multimedia, karena multimedia efektif untuk mengelola beban kognitif intrinsic, mengurangi beban kognitif extraneous dan meningkatkan beban kognitif germane.

Dari penjelasan diatas dapat disimpulkan bahwa untuk mendeskripsikan penerapan pembelajaran berbasis multimedia berdasarkan teori beban kognitif yang dapat meningkatkan kemampuan menyelesaikan masalah mata pelajaran motor bakar, khususnya materi motor bakar.

\section{METODE}

Penelitian ini dilakukan di SMK Nila Harapan Deli Serdang di kelas semester ganjil X akademik tahun 2016 2017. Metode yang digunakan dalam penelitian ini adalah penelitian dan pengembangan karena penelitian ini mencakup pengembangan penelitian pendidikan yang dimaksudkan untuk menghasilkan layak belajar digunakan hemat biaya dan sesuai kebutuhan. Pengembangan model adalah serangkaian prosedur untuk menghasilkan mesin konversi energi media pembelajaran.

Dalam penelitian dan pengembangan, model yang dikembangkan mengacu pada penelitian dan pengembangan model Borg dan empedu (2005) dikombinasikan dengan model pengembangan Dick dan Carey (2005) yang memiliki pengembangan langkah sebagai berikut:

1. Penelitian pendahuluan, yang meliputi: (a) identifikasi belajar kebutuhan dan menentukan subyek standar kompetensi, (b) mempengaruhi analisis belajar, (c) identifikasi karakteristik dan perilaku awal; (d) menulis kompetensi dasar dan biaya indikator akan, (e) menulis referensi patokan ujian; merakit strategi pembelajaran yang terdiri dari; Deskripsi tujuan pengajaran; Penjelasan tentang relevansi konten baru;

2. Deskripsi bahan pembelajaran atau konsep, prinsip-prinsip dan prosedur yang akan belajar belajar; Test formatif; Tanggapan; tindak lanjut, (f) mengembangkan bahan belajar.

3. Pembuatan software desain, yang meliputi: (a) pembuatan naskah, (b) pembuatan papan cerita, (c) membuat tampilan diagram alur.

4. Koleksi bahan-bahan yang meliputi penciptaan dan koleksi gambar dan animasi,

5. penciptaan rekaman audio meninjau

6. menguji produk tes efektif produk

Analisis data dalam penelitian ini menggunakan analisis kuantitatif deskriptif. Semua data yang dikumpulkan dianalisis dengan teknik statistik deskriptif yang secara kuantitatif dipisahkan menurut kategori untuk mempertajam penghakiman dalam mengambil kesimpulan. Data kualitatif dalam bentuk pernyataan sangat kurang baik, kurang baik, moderat, sangat bagus dan sangat baik dikonversi ke data kuantitatif dengan nilai skala 1 sampai 5. Hasilnya adalah dirata-rata dan digunakan untuk menilai kualitas perangkat lunak instruksi. Kriteria perangkat lunak akan dikonversi menjadi nilai dengan skala skala Likert yang menggunakan lima dianalisis dalam persentase deskriptif (Sugiyono, 2007).

Penduduk dalam penelitian ini adalah tahun ajaran Nila Harapan Deli Serdang kejuruan sekolah tinggi 20162017 kelas X dan terbagi menjadi dua kelas, kelas $\mathrm{B}$ dan percobaan sebagai kelas kontrol, masing-masing sebanyak 25 orang.

Dalam studi ini data yang diperoleh adalah hasil belajar siswa dari kelas eksperimen dan kontrol kelas. Teknik analisis data yang digunakan adalah teknik deskriptif dan Inferensial. Teknik statistik deskriptif yang digunakan untuk menganalisis data dengan cara menggambarkan data yang telah dikumpulkan sebagai-tanpa berniat untuk membuat kesimpulan umum yang berlaku untuk atau generalisasi. 
Sebagai contoh, presentasi dari data menggunakan tabel, grafik, diagram lingkaran, pictogram, perhitungan modus, median, berarti, desil, persentil, rata-rata, deviasi standar, orang, korelasi dan regresi pengujian tanpa makna. Inferensial teknik yang teknik statistik untuk menganalisis data sampel data dan hasilnya berlaku untuk penduduk. Kesimpulan dari data sampel yang akan berlaku untuk penduduk yang memiliki kesempatan untuk kesalahan dan kebenaran (kepercayaan).

Penelitian hipotesis diuji adalah:

HO: $\mu \mu \leq \mathrm{A} 1 \mathrm{~A} 2$

H1: $\mu \mu>$ A1 A2

Dengan Keterangan

$\mu$ A1 : Rata-rata hasil pembelajaran motor bakar siswa dengan menggunakan media pembelajaran interaktif.

$\mu$ A2 : Rata-rata hasil belajar pembelajaran motor bakar siswa tanpa menggunakan media pembeljaran interaktif.

Untuk menguji hipotesis tes digunakan formula dua sisi. Kriteria uji menerima $\mathrm{Ha}$ jika $\mathrm{t}$ menghitung $>\mathrm{t}$ meja Diperoleh dari daftar distribusi $\mathrm{t}$ dengan $\mathrm{dk}$ $=(\mathrm{n}-1)$ dan tingkat $=5 \%$. Untuk melihat nilai efektivitas media interaktif pembelajaran percobaan digunakan formula perhitungan efektifitas.

\section{HASIL DAN PEMBAHASAN Hasil}

Produk pengembangan media interaktif pembelajaran motor bahan bakar adalah produk yang telah dikembangkan dengan memperhatikan aspek-aspek pembelajaran, sehingga dihasilkan produk yang layak digunakan sesuai dengan karakteristik dan bidang studi siswa. Produk pengembangan penelitian dilakukan ditujukan untuk menghasilkan produk dalam bentuk interaktif belajar energi media pembelajaran mesin konversi untuk siswa kelas X Nila Harapan Deli Serdang sekolah menengah kejuruan, digunakan untuk meningkatkan proses belajar dan meningkatkan hasil belajar siswa.

Hasil validasi interaktif belajar media dari validator, yaitu (1) total hasil penilaian oleh ahli materi dari aspek tampilan, presentasi, serta struktur konten media belajar adalah $87 \%$ oleh kriteria "sangat bagus". total (2) hasil penilaian oleh desain instruksional ahli terhadap media interaktif pembelajaran mesin konversi energi mengembangkan menunjukkan bahwa kualitas desain instruksional memperoleh persentase Skor total $84 \%$ dari kriteria "sangat baik". total (3) hasil penilaian oleh ahli media pembelajaran terhadap media interaktif pembelajaran pembelajaran mesin konversi energi dikembangkan menunjukkan bahwa layar, render, serta grafis mendapat persentase dari total score kriteria 83\% " Sangat baik ".

Sedangkan perhitungan respon siswa diperoleh, yaitu (1) mahasiswa respon terhadap media interaktif pembelajaran pada aspek belajar tampilan media, umumnya dinyatakan sangat baik dengan hasil peringkat $82 \%$. (2) respon dari para siswa terhadap media presentasi interaktif belajar umumnya baik dinyatakan oleh hasil peringkat $80 \%$ (3) respon siswa pembelajaran media pada manfaat dari media interaktif pembelajaran, umumnya dinyatakan sangat dengan $81 \%$ peringkat hasil.

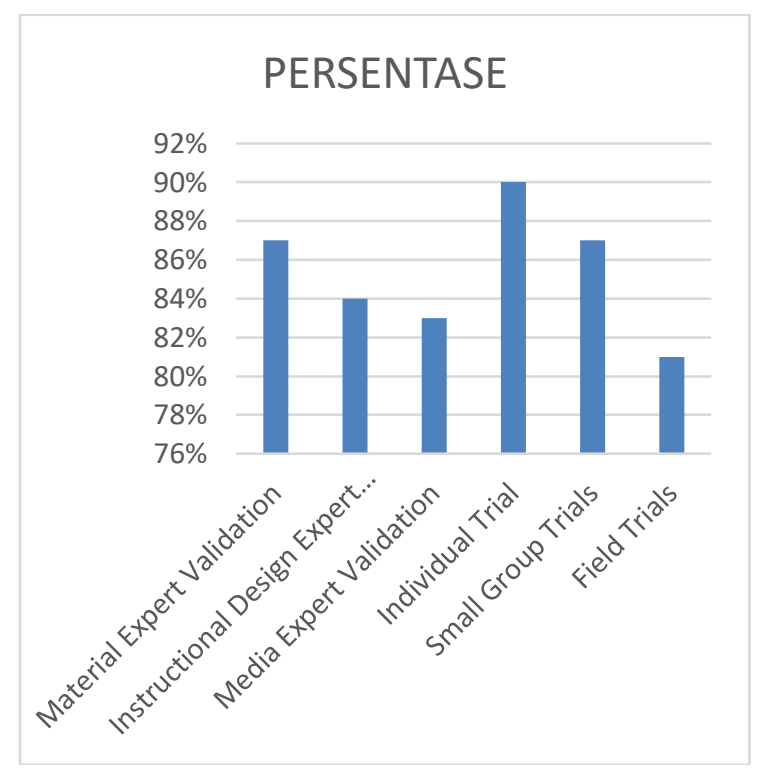

Gambar 1. Ringkasan persentase ahli validasi \& siswa Respon terhadap Media interaktif pembelajaran.

Diagram di atas adalah hasil dari diskusi tentang uji kelayakan media interaktif pembelajaran mata pelajaran konversi energi. Pengembangan produk interaktif belajar media bahan bahan bakar motor adalah produk yang telah dikembangkan dengan memperhatikan aspek pembelajaran, sehingga menghasilkan produk yang layak digunakan sesuai dengan karakteristik bidang studi dan siswa. Penelitian pengembangan produk ini ditujukan untuk menghasilkan produk dalam bentuk media interaktif pembelajaran mesin konversi energi belajar bagi siswa kelas $\mathrm{X}$ dari Nila Harapan 
Deli Serdang kejuruan sekolah tinggi, digunakan untuk meningkatkan proses belajar dan meningkatkan hasil belajar siswa.

Hasil validasi interaktif belajar media dari validator, yaitu (1) total hasil penilaian oleh para ahli bahan dari aspek tampilan, presentasi, dan struktur pembelajaran konten media adalah $87 \%$ dengan kriteria "sangat Baik". (2) maka total hasil penilaian oleh desain instruksional ahli pada media interaktif pembelajaran mesin konversi energi mengembangkan menunjukkan bahwa kualitas desain instruksional memperoleh persentase total nilai $84 \%$ dengan kriteria" Sangat bagus". (3) total hasil penilaian oleh media belajar ahli pada pembelajaran interaktif media mesin konversi energi yang berkembang menunjukkan bahwa tampilan, presentasi, dan grafik mendapatkan nilai persentase 83\% dengan kriteria "Sangat bagus". Sementara mahasiswa respon perhitungan diperoleh, yaitu (4) mahasiswa menanggapi interaktif belajar media pada aspek tampilan media instruksional, umumnya dinyatakan sangat baik dengan hasil penilaian 90\%. (5) siswa menanggapi media interaktif pembelajaran pada aspek presentasi umumnya dinyatakan baik dengan peringkat hasil 87\% (6) siswa menanggapi media instruksional pada aspek manfaat media interaktif pembelajaran, umumnya dinyatakan sangat baik dengan hasil peringkat $81 \%$

\section{Pembahasan}

Produk

pengembangan media pembelajaran interaktif pada mata pelajaran motor bakar merupakan materi yang telah dikembangkan dengan memperhatikan aspek pembelajaran dan media sebagai dasain pesan pembelajaran. Penelitian pengembangan ini dilakukan untuk menghasilkan suatu produk berupa CD pembelajaran media interaktif motor bakar untuk kelas X SMK teknik otormotif yang bermanfaat untuk meningkatkan hasil belajar siswa.

Proses penelitian ini diawali dari studi pendahuluan, pengumpulan data/materi pelajaran, membuat desain software, membuat dan memproduksi software, review dan uji produk yang divalidasi oleh ahli materi, ahli desain instruksional dan ahli media, melakukan analisis data, revisi produk sehingga layak digunakan oleh pengguna yaitu uji coba perorangan, kelompok kecil dan uji lapangan serta penilaian dari pengguna tersebut sehingga menghasilkan produk yang layak dan bermanfaat dalam pelaksanaan proses pembelajaran.

Revisi dilakukan berdasarkan atas penilaian, saran dan komentar dari para ahli materi, ahli desain instruksional dan ahli media pembelajaran serta pengguna medai tersebut yang bertujuan untuk menghasilkan produk media yang layak pakai. Variabel-variabel media pembelajaran memiliki rata-rata sangat baik. Adapaun variabel media pembelajaran yang dinilai meliputi kelayakan isi, penyajian, kebahasan, pemrogaman dan kegrafikan.

Manfaat yang diperoleh dalam menggunaka media interaktif pembelajaran adalah konsep yang disajikan mudah dipelajari, dipahami dan sistematis. Media interaktif pembelajaran motor bakar memberikan kesempatan kepada peserta didik untuk belajar sesuai dengan karakternya masing-masing, mudah dipahami karena materi dilengkapi dengan gambar dan animasi serta video motor bakar, komponen motor bakar, dan mekanisme kerja motor bakar. Produk media ini dikemas dalam benrtuk CD yang dapat digunakan dalam pembelajaran secara mandiri mauun klasikal juga dilengkapi dengan latihan menjawab soal untuk mengetahui daya serap siswa setelah selesai proses pembelajaran.

Hasil rangkuman persentase rata-rata hasil penilaian terhadap media interaktif pemebelajaran motor bakar oleh ahli materi, ahli desain instruksional, ahli media, uji coba perorangan, kelompok kecil dan kelas eksperimen/kelompok besar.

\section{PENUTUP}

Pertama, Berdasarkan Hasil Penilaian Validasi Ahli Materi, Ahli Desain Instruksional, Ahli Materi dan Ujicoba Media Pembelajaran Interaktif terhadap media pembelajaran interaktif pembelajaran Motor Bakar yang dikembangkan menunjukkan bahwa kualitas desain pembelajaran memperoleh persentase skor total sebesar 85\% termasuk kategori "Sangat Baik" dan "Layak Untuk Digunakan" dengan Revisi.

Kedua, Berdasarkan dari hasil pengolahan data nilai rata-rata hasil belajar siswa yang menggunakan media inetraktif dengan hasil belajar siswa yang menggunakan media cetak menunjukkan bahwa siswa yang menggunakan media pembelajaran interaktif "lebih efektif" daripada siswa yang menggunakan media cetak. Hail itu ditunjukkan dengan hasil analisis $t_{\text {hitung }}$ $>t_{\text {tabel }}(2,18>1,99)$. 


\section{DAFTAR PUSTAKA}

Aditia dkk. Implementasi Augmented Reality (AR) Pada Pengenalan Ikan Hias Menggunakan Metode Markerless BerbasisAndroid. handle/123456789/60486,diakses 12 Oktober 2016.

Andria. "Arca, Pengembangan Buku Interaktif Berbasis Augmented Reality dengan smarthone Android". Jurnal Nasional Teknik Elektro dan Teknologi Informasi (JNTETI) 3.2, 2014

Azuma, R T. 2007. A Survey of Augmented Reality. Presense:Teleoperator and Virtual Environment. 2007 : 2 \& 3

Cheng, P dkk. A Review of Using Augmented Reality in Education from 2011 to 2016. Springer: Innovation in Smart Learning, 2016.

Khairnar, K dkk. Furniture Layout Application Based on Marker Detection and Using Augmented Reality, 2015.

Magdalena M. The Field Play Mobile Application: Augmented Reality, Location-Aware Content, And The Creation Of An Interactive, Data- Rich Digital Educational And Research Tool. 168, 2016.

Mauro F. Teaching Mathematics With
Augmented Reality.12th International

Conference on Technology in Mathematics Teaching, 2015.

Listiyani, Dini. Intel Bikin Saingan Google Glass\&HoloLend 2016/03/04/57/1327554/intel-bikinsaingan- google-glass-hololens, diakses pada tanggal 14 Oktober 2016.

Jessnor E, dkk. The Use Of Augmented Reality (AR) Among Tertiary Level Students: Perception And Experience.Australian Journal of Sustainable Business and Society 2.1, 2016.

Paivio, Alan \& Mark. A Dual Coding Theoretical Model of Reading.Citeseer, 2004.

Saguni, F. Prinsip-Prinsip Kognitif Pembelajaran Multimedia: Peran Modality dan Contiguity Terhadap Peningkatan Hasil Belajar. INSAN Vol.8 No. 3, 2006.

Suppiah. Peranan Teori Dual Coding Dan Proses Kognisi Dalam Pengajaran Dan Pembelajaran Melalui Kaedah Pedagogi Hermeneutik. Jurnal Pendidikan BITARA UPSI, Vol 6/2013, 2013

Wendra, I W.Tingkat Kekohesifan Abstrak Dalam Artikel Aneka Widya.Jurnal Pendidikan dan Pengajaran IKIP Negeri Singaraja. 